\title{
A BRIEF VIEW ON BILINGUAL SCHOOLS IN THE CAPITAL OF INDONESIA
}

\author{
Annas Surdyanto \\ Pamulang University, Banten, Indonesia \\ (annas.surdyanto@gmail.com)
}

Received: $18^{\text {th }}$ March 2018; Revised: $25^{\text {th }}$ May 2018; Accepted: $28^{\text {th }}$ June 2018

\section{ABSTRACT}

This study aimed at providing the portraits of bilingual schools in the capital of Indonesia and critically revealing the Ministry of Culture and Education policy on bilingual schools. This study employed a qualitative case design and took place at 5 bilingual schools. The data were taken with semi-structure interview, school document, observation and related literature. There were 10 teachers participating. This study showed descriptions of bilingual schools regarding the curriculum, the teaching and learning activity, the assessment, the accessibility, the teachers, the students, and the role of environment. The data derived were then analyzed and used to evaluate the government policy on bilingual schools related to the process of teaching and learning as well as its assessment. The analysis and evaluation found out some missing alignments between the policy and bilingual school principles. They were uncontrolled curriculum development as a combination of international and national curriculum, the Teacher Training Program provided by the government (PLPG) towards bilingual school teachers, and the establishment of standardized test. This study suggested that there must be an education council specialized for bilingual schools that concerns on designing the framework of school-based curriculum development (SBCD), teacher training program and standardized test establishment for bilingual schools.

Key Words: bilingual education; policy on bilingual education; bilingualims; Indonesian bilingual schools

\begin{abstract}
ABSTRAK
Penelitian ini bertujuan untuk menyediakan potret sekolah bilingual di ibukota Indonesia dan mengungkapkan kebijakan Kementerian Pendidikan dan Kebudayaan di sekolah bilingual secara kritis. Penelitian ini menggunakan desain kasus kualitatif dan berlangsung di lima sekolah bilingual. Data diambil dengan wawancara semi-struktur, dokumen sekolah, observasi dan literatur terkait. Ada 10 guru yang berpartisipasi. Penelitian ini menunjukkan deskripsi sekolah bilingual mengenai kurikulum, kegiatan belajar mengajar, penilaian, aksesibilitas, guru, siswa, dan peran lingkungan. Data yang diperoleh kemudian dianalisis dan digunakan untuk mengevaluasi kebijakan pemerintah pada sekolah bilingual yang terkait dengan proses pengajaran dan pembelajaran serta penilaiannya. Analisis dan evaluasi menemukan beberapa keberpihakan yang hilang antara kebijakan dan prinsip sekolah bilingual. Mereka adalah pengembangan kurikulum yang tidak terkendali sebagai kombinasi kurikulum internasional dan nasional, Program Pelatihan Guru yang disediakan oleh pemerintah (PLPG) terhadap guru sekolah dwibahasa, dan pembentukan tes standar. Studi ini menyarankan bahwa harus ada dewan pendidikan khusus untuk sekolah bilingual yang berkaitan dengan merancang kerangka pengembangan kurikulum berbasis sekolah (SBCD), program pelatihan guru dan pendirian tes standar untuk sekolah bilingual.
\end{abstract}

Kata Kunci: pendidikan bilingual; kebijakan pendidikan bilingual; dua bahasa; Sekolah bilingual bahasa Indonesia

How to Cite: Surdyanto, A.. (2018). A Brief View on Bilingual Schools in the Capital of Indonesia. IJEE (Indonesian Journal of English Education), 5(1), 1-15. doi:10.15408/ijee.v5i1.8018 


\section{INTRODUCTION}

Prior to Indonesian independence, English has never been used as a medium of Indonesian discourse by Indonesian people due to the lack of native speakers of English (Lowenberg, 1991). Different from other ASEAN countries which had set English as a second language or additional language in curriculum, after its independence day, Indonesia concerned on spreading Indonesian as its national language and have converted people to become bilingual of regional language and Indonesian (Ho \& Wong, 1997). On the other hand, English in Indonesia is used for international communication, knowledge of science and technology, as a modern language sources for the lexical development of Bahasa Indonesia (Diah, 1982 as cited in Lowenberg, 1991).

In 1989, Indonesian government specialized English as a compulsory subject in curriculum. The 1994 curriculum specifies English lesson for 180-minute periods per week in middle schools and for up to 11 hours per week at senior high schools (Hill \& Mcnamara, 2003). Nevertheless, the presence of English that is a foreign language still requires sufficient places and opportunities to enable learners to have good English skills since a successful second language learning will take place if there is a sufficient target language exposure (Krashen, 1982).

As it is predicted by Lauder (2008) that the demand for English in the future of Indonesia will increase even if the state policy makers do not meet the need, the private sector will take place to fulfill the need. Responding to the needs of place and opportunity of English use in educational field, many schools emerge adopting bilingual principles which refer to the presence of two languages in a community possessing the same language. Indonesian bilingual schools apply the use of English and Indonesian as a media of instruction to provide more opportunities for students to use English. Regarding the language policy, common type of bilingual programs in Indonesia is two-way or immersion programs. It concerns on the progress of both minority and majority language (Lindholm-Leary, 2001). Nizamia Andalusia School is one of bilingual schools establishing the two-way bilingual program in Jakarta, Indonesia. It applies English to supply students with international language to encounter globalization era.

In the capital of Indonesia, many bilingual schools operate under the supervision of the Ministry of Culture and Education. Unfortunately, these 
schools have no specific regulation that is specialized for them. The notion of equality in education has put them in a generalized school view of the government. They are treated the same way as public schools. However, it can cause some problems that can constrain the process of bilingual education. This might happen due to the insufficient information about bilingual schools. Furthermore, it seems that they have no attention from Indonesian government. Thus, this study is proposed to provide the portraits of bilingual schools in the capital of Indonesia for further policy decision.

\section{METHOD}

This qualitative research has been conducted in Jakarta, the capital of Indonesia. Semi-structure interview was delivered to 10 experienced teachers of bilingual schools. Most of them were teachers who had experienced in teaching more than in two bilingual schools. In the interview, they were asked to explain about bilingual schools that they had experienced. It broadens this research not only to be based on the schools that they were teaching but also the schools they had taught previously. The interview was conducted to have a description about what bilingual school curriculum is, how teachers teach, how the government provides them a program of teacher training, and constraints of teaching and administration they have.

To have a clear description of the outlook of the bilingual schools, besides interviewing the teachers, the writer also elaborated his five-year experience in teaching in a bilingual school while observing the school. Moreover, the school document and website were also analyzed. Some issues derived from the interview, observation, and school document were also analyzed and discussed.

\section{FINDINGS AND DISCUSSION The Curriculum}

To ease in understanding bilingual school curriculum, it is important to have a clear definition of what curriculum is. The definition of curriculum has been clearly explained by Glatthorn (1987), "the curriculum is the plans made for guiding learning in schools, usually represented in retrievable documents of several levels of generality, and the implementation of those plans in the classroom; those experiences take place in a learning environment that also influences what is learned".

In other words, curriculum is an essential school document consisting of guidance for teachers, school staffs, 
policy makers, students, parents, and all school elements contributing in the teaching and learning process. Bilingual school curriculum is generally a developed curriculum. According to Seel (2004) "the central issue of curriculum development is to allocate the contents and methods that are seen as relevant for the challenges in the students' present and future life."

The data from interview and observation have given a clear description of curriculum of Indonesian bilingual schools. Generally, bilingual schools combine two curricula in their learning environment which are international curriculum and national curriculum. The international curriculum is applied for Math, Science, English Lesson, ICT, Physical Education, and Social Studies. The purpose is to prepare students with a good ability of English as international language to be competitive in the future.

Meanwhile, the national curriculum is used for Civics, Religion, and Indonesian Language. This is applied to empower the spirit of nationalism as it is listed in the rational of recent curriculum development. The national curriculum now adopts a thematic approach which requires all subjects to be integrated into one theme. It has conjoined science and social studies in Indonesian Language Subject, and it contradicts the international curriculum which has Science and Social Studies as independent subjects. However, it is difficult for teachers to apply thematic approach for its implementation since both national curriculum and international curriculum have different contents and approaches.

The description above has delivered a question "how do these schools set the goals of education?" When these schools operate two curricula under a council that supervises based on the national curriculum only, it is really possible that there is a hidden curriculum as a medium for these two contradicting curricula as it is defined as "a side effect of an education, "[lessons] which are learned but not openly intended" (Martin, 1983) "such as the transmission of norms, values, and beliefs conveyed in the classroom and the social environment" (Giroux, 1983).

In conclusion, bilingual educations have to stand under the right council that professionally concern on this complex principle. Consideration in grading rank of schools should also be categorized and based on its special criterion. Even though it is not a simple thing to do, bilingual schools need a special 
attention that can be guidance for their existence.

\section{Teaching and Learning Activity}

Bilingual education is a type of education that uses students' native language and English in subject-matter instruction (Martin \& Loomis, 2014). Students' native language is commonly combined with English as medium of instruction before they are placed in completely English class. In Indonesia, students' native language is Indonesian. According to Būdvytytě-Gudieně \& Toleikieně (2008), there are three types of bilingual education. The first type is 'immersion', this type aims at a country's other language (e.g. Canada, Belgium, Ireland, Luxembourg, Malta, Finland and Switzerland) or regional language (Slovenia and United Kingdom). The second kind, so-called 'submersion', refers to the integration of linguistic and culture of migrants (the linguistic minority). The third type is where the target group is linguistic majority and the target language is a foreign language of a certain country. The status of English in Indonesian that is a foreign language defines that Indonesian bilingual schools categorically belong to the third type of bilingual education.

As the third type of bilingual education, Indonesian bilingual schools apply Content and Language Integrated
Learning (CLIL) as their teaching and learning method since it is more appropriate to be implemented instead of Content-Based Instruction (CBI). The content or subject matters delivered in English as a language of instruction (LOI) are Math, Science, and Social Studies in both learning activities and assessment.

Bilingual schools have various language policies depending on what type of bilingual they belong to. Johnson (2013) explains that a language policy has impacts on structure, function, use or acquisition of language. Therefore, a language policy is decisive for schools to be a vehicle of curriculum, goal, culture, as well as the teaching and learning process. The type of bilingual, two-way bilingual is established in its curriculum. The aim of this bilingual type is to encourage its national identity (Bahasa Indonesian) and meeting the need of current internationalization (English). The twoway bilingual education program concerns on the progress of both minority and majority language (Cummins \& Corson, 1997). The twoway bilingual class uses students' native language and second language in particular proportion in which the development of languages is emphasized.

\section{Assessment}


Generally, Indonesian bilingual schools have designed their assessment as other public schools related to the implementation of either formative or summative test. Formative assessment which is applied to evaluate students in the process of learning and help students to continue their achievement (Brown, 2004), is delivered to students in the middle of the semester. The feedback is usually established in the next meeting as a constructive feedback for students. Meanwhile, regarding the summative assessment, as it purposes to measure what students have achieved at the end of the course (Brown, 2004), there is no direct feedback given by teachers to students, but the summary of its feedback is informed to parents or the representatives by teachers in report day.

Besides, Indonesian bilingual schools should apply the National Standard School Exam (USBD), so called standardized test. This test is applied for particular subjects such as Math, Science, and Social Studies in the highest school grade levels: grade 6 of primary school, grade 9 of middle school, and grade 12 of high school. As students certified by the Ministry of Culture and Education, to have graduated and certified, bilingual school students have to pass the minimum score determined by the ministry of education in this test.

The standardized test is a really strange thing for bilingual schools due to the medium of instruction of the test that is not English but Indonesian language. Interviewed teachers complained that students frequently have difficulty when they are asked to try out this kind of exam in Indonesian language. However, it is out of their school traditions in which English is always used for both its formative and summative assessments for those subjects. Moreover, bilingual school students have learned subjects examined using English as the medium of instruction for years.

\section{Accessibility}

Looking back at the era of bilingual school trend in support of Indonesian government, Indonesia has a long controversial history of bilingual school existence. The policy of the International Standard School project (SBI) (Article 50, paragraph 3, of Law No. 20/2003) has been caused pros and cons around Indonesian people. Due to the high cost and academic prerequisite of SBI students, it was adjudicated contradicting the Constitution which guarantees education for all Indonesian people. Under the intense debate on whether SBI was appropriate to be applied, the Judicial Court revoked the 
law foundation of SBI regardless of its potential outcomes. Despite the fact that the biggest problem of the SBI program was the high cost that absorbs large amount of Indonesian education budget, bilingual schools which provide global competitive skills are still running in private sectors.

Indonesian bilingual schools, as it requires a high tuition fee of students, has become exclusive schools among Indonesian people. Generally, students who study in bilingual schools are those who are from high economic class citizens. It is an inevitable consequence since bilingual schools tends to facilitate their children with outstanding school facilities. Students who enroll at bilingual schools should be ready for not only high cost tuition fee but also other additional courses to support their learning process such as English course.

Nevertheless, concerning on how accessible bilingual schools in Indonesia, for bilingual kindergarten and primary schools, language is not an abundant for Indonesian children to study in this school since research has shown that those who are not from school with English language background can finally adapt after having additional courses even though they might have low confidence at the first school phase (Surdyanto, 2016).
In other words, bilingual school accessibility is categorically difficult for citizens with middle and low economic class. The middle class citizens might be able to enroll their children and pay the tuition fee of bilingual school, but they have to endeavor to support either their children development or additional school programs such as study tour, Cambridge ESOL etc.

\section{The Teachers}

Teachers in schools might be recognized as school members that are directly responsible for the success of teaching and learning. Teachers' in bilingual schools not only responsible for knowledge transfer but also for the success of reaching school visions. As it is stated by the Crowther Report that 'everything in education depends ultimately on the teacher' (Central Advisory Council for Education, 1959), the completion of bilingual school curriculum.

Being bilingual school teachers in Indonesia is not as simple as being public school teachers. Teachers of bilingual school have to possess a good understanding of particular subject matter as well as the medium of instruction used for the subject. For example, teachers who are a good scholar of Department of Math Education cannot teach in bilingual school. They have to be able to teach 
Math in English as a medium of instruction.

In reality, those who teach in bilingual schools are teachers who are good at both English language use and subject matter. These multi-demands force bilingual schools to selectively employ teachers not only based on their GPA score or bachelor degree but also their ability in both subject matter and medium of instruction. As a result, the provision of bilingual teachers is very limited since the status of English in Indonesia that is a foreign language.

Indonesian bilingual school teachers are divided into three categories. The first is bilingual school teachers who are not from the Department of Teacher Training and Education. They have graduated from Department of Economy, Communication, Accounting, Social Studies, etc. who can use English to teach particular subject matter. Second, those who graduated from the Department of Teacher Training and Education majoring at Science, Biology, and Math. These two types of bilingual teachers are expert in particular subject matter, but some of them need to improve their English. The third, those who graduated from English Department of Teacher Training and Education. These bilingual teachers know well how to work with their
English but they have to struggle once they are asked to teach Math, Science, and other subjects except English Lesson.

With regard to school culture, bilingual schools have their own culture that is not applied outside school areas. Being a bilingual school teachers or teacher aides cannot merely rely on the ability of delivering the school materials. Teachers should recognize cultures underlying the two languages applied in bilingual schools. Bilingual teacher aides, however, are a bridging instrument for students between the hearts and minds of their initial culture and the target language culture (Haddock et al., 2008).

\section{The Students}

Are bilingual school students really bilingual? This question needs answering to clearly shed light who the bilingual school students are, but it is essential to have an in-depth definition of what bilingual really is. The judgment towards the term of bilingual or whom can be labeled as bilingual is still misleading. Bilingual in the view of strong monolingual or fractional according to Grosjean (1989) is the bilingual who possess two languages in two separated and isolable competencies - so called - two monolinguals in one person. Bilingual students who are linguistically 
accidental and anomalous or committing to language interference such as borrowing and code switching are under the bilingual definition of monolingual view.

Meanwhile, in the view of wholistic bilingual, the bilingual is he or she whose language is not the sum of two languages but having a unique and specific linguistic configuration. Grosjean (1989) explains that the bilingual has a third system which is the combination of two languages rather than two-separated languages.

"Because the bilingual is a human communicator, he or she has developed a communicative competence that is sufficient for everyday life. This competence will make use of one language, of the other language, or of the two together (in the form of mixed speech) depending on the situation, the topic, the interlocutor, etc."

The third system of bilingual is defined to be the creation of successful two-language acquisition and development. Thus, he or she who are, in the wholistic view, bilingual can use both languages in a good communicative competence for his or her everyday life. For example, students might be good at Indonesian and English and they can use either Indonesian or English or both languages depending on the condition, theme, and his/her interlocutors. However, this unique ability is a combination of two-language competence that are not isolated.

Regardless of the monolingual or wholistic bilingual view, judgment to which Indonesian bilingual school students refer to is still difficult to be determined since they come from various language background and education background (Surdyanto, 2016). Nevertheless, identification is still important to be conducted to see what kind of bilingual they belong to. Understanding the process of becoming bilingual and the monolingual and wholistic bilingual view is important for education decision makers to avoid inappropriate implementation of policy and regulation for bilingual schools related to school language policy of both the teaching and learning process and assessment.

Furthermore, most bilingual school students have been able to use both English and Indonesian, but it is not for all contexts. As Cummins (1981) distinguished language into two contexts that are basic interpersonal skills (BISC) and cognitive academic language proficiency (CALP), Indonesian bilingual school students are lack of Indonesian language ability in the context of CALP for particular subjects such as Math, Science, and 
Social Studies, but good in the context of BISC.

\section{Role of Environment}

Vygotsky (1978) asserts that social behaviors have a fundamental role to influence children's development when they are involved. This theory, zone of proximal development (ZPD), explains that children learn from their community such as parents, teachers, and adults long before they are at school. Vygotsky's idea in thought and language describes that the growing children adopt social language and make it personal. It can be assumed that language that happens to children shapes the children's language development. In other words, children learn from the community around them.

Since parents spend much more time with their children than other people around them, parents are the most likely responsible for children's school readiness and social adjustment. As a consequence, they must contribute and become a model of children's language development. According to Lin and Man's studies (2009) on Southeast Asian Perspectives on Bilingual Education, bilingual schools should implore parental commitment to support children's development of both languages as a requirement to enroll in English immersion program. Thus, two- way bilingual programs need supports from parents to reach the highest level of language proficiency. Therefore, parental involvement is very important to support children's development and the success of school program, it is crucial to have a clear description of parental role towards school program.

In addition, Reynolds and Clements (2005) describe that parent involvement give significant contributions to children's success. The one component of parent involvement program is to promote children's school readiness and social adjustment. The training areas include consumer education, nutrition, personal development, health and safety, and homemaking arts with assets for materials, supplies, and speakers. It shows that parents are responsible for preparing children and helping them adjust themselves in school environment. To complete, Reynolds and Clements (2005) emphasize that what can impact on children's school success are school-family partnerships consisting of many ways to strengthen involvement.

In conclusion, parental involvement is not only essential for students' academic achievement, but also for their language acquisition. By this fact, there is a different parent role between Indonesian public schools and 
bilingual schools. For public schools, parental role on foreign language acquisition is not really essential for due to the national school curriculum that does not use English as a medium of instruction for any subjects. In other words, limited English ability will not be a significant constraint for students to have a good school achievement. Meanwhile, for bilingual schools in which international curriculum is used, parental involvement is a considerable need for students to have a good school achievement since international curriculum is applied in Indonesian bilingual schools.

\section{Policy Evaluation}

Indonesian education today has such its own needs of globalization that private schools want to meet the needs by their own way. Since bilingual schools run on their own vision, the government policy should take a look at their vision before deciding policy related to all aspects of the teaching and learning process. Considering a significantly increasing number of bilingual schools in Indonesia, it is important to make an accurate and appropriate regulation for bilingual schools. However, Indonesian bilingual schools running with their own curriculum which is comprised of national and international curriculum. In other words, bilingual schools apply school-based curriculum which, according to Bezzina (1991), can be a creation of new curricula, adaptation of existing curricula, and adoption of an existing curriculum.

In order to have a non-overlapping school-based curriculum, there should be guidance for school-based curriculum development (SBCD). Bolstad (2004) draws some important systemic influences of SBCD that is important factors to shape school-based curriculum:

1. the structure and nature of the national curriculum;

2. the degree of centralisation/decentralisation of school decision making

3. schools' assessment and reporting requirements;

4. the expected role of teachers in school curriculum development; and

5. the expected or potential role of other people in school curriculum development

Indonesian government should change its point of view that bilingual schools can be accredited the same way as public schools. This classic view should be immediately banned to prevent malpractice of education. Unfortunately, Indonesian government 
seems to close its eyes on this phenomenon. For example, instead of providing a training for bilingual school teachers, the government mandates bilingual school teachers to follow a general training that is actually more appropriate to be addressed for nonbilingual school teachers such as Teacher Training Program (PLPG). This training might be useful for bilingual school teachers who teach using Indonesian medium of instruction. For teachers who teach Science, Social Studies, and Math, they might have benefits in the aspect of material development but not in cultural aspects.

In addition, the bilingual types of students should also be considered since the test uses Indonesian Language as its medium of instruction and it will be bias for bilingual schools that are dominated by students who are not wholisticly bilingual. Moreover, the government should be aware of what kind of language aspect that bilingual students master in term of basic interpersonal skills (BISC) and cognitive academic language proficiency (CALP). Students mastering Indonesian language, however, do not exactly master Indonesian language of CALP.

Regarding the establishment of the standardized test, as bilingual school teachers affirmed that students generally have difficulties for preparing the standardized test due to the language use that is different from what they used to do, this examination is not only a challenge for students but also teachers and the school language policy. Moreover, its establishment has caused not only impact on curriculum but also on teaching and learning process. However, as a fair test, assessment must be free of biases with regards to ethnic group, gender, nationality, religion, socioeconomic condition, sexual orientation, or disability (Joint Task Force on Assessment 2010). As a comparison, when blind students can work with braille or verbal guidance of teachers as fairness, why do bilingual students have to work in one language that they do not use to apply in learning Math, Science, and Social Studies? It is so important that educationists have to pay attention on. Indonesian government through the Ministry of Education and Culture has to adopt the idea of how the National Assessment Program - Literacy and Numeracy (NAPLAN) identifies students' language background of English in delivering standardized test by which it distinguishes Native English and Language Other Than English (LBOTE). Despite the criticism of its categorization (Creagh, 2014), it can be 
a good milestone in pursuing valid equality in education.

\section{CONCLUSION AND SUGGESTION}

Bilingual schools in the capital of Indonesia are currently well renowned. They are getting their place in the heart of the capital citizens. This phenomenon should be responded wisely by the government. The Ministry of Culture and Education has to immediately categorize Indonesian schools based on their criteria.

Descriptions of bilingual schools regarding the curriculum, the teaching and learning activity, the assessment, the accessibility, the teachers, the students, and the role of environment should have been a warning for the policy makers. However, generalization of policy will not support the schools to meet their visions since they have different ways and goals. Educationists should have opened their eyes to respond this changing world.

\section{REFERENCES}

Bezzina, M. (1991). Teachers' Perceptions of Their Participation in School Based Curriculum Development: A Case Study. Curriculum Perspectives, 11 (2), 39-47.

Bolstad, R. (2004). School-based Curriculum Development: Redefining the Term for New
Zealand Schools Today and Tomorrow. Paper presented at the conference of the New Zealand Association of Research in Education (NZARE). Wellington.

Brown, H. D. (2004). Language Assessment: Principles and Classroom Practices. White Plains, NY: Pearson Education.

Būdvytytě-Gudieně, A. and Toleikieně, R. (2008). Content and Language Integrated Learning: Features of Educational Methods. (cover story). Social Sciences (1392-0758) 60, 9097.

Central Advisory Council for Education. (1959). The Crowther Report, 15 to 18 Vol. 1. London, HMSO

Creagh, S. (2014). National Standardised Testing and the Diluting of English as a Second Language (ESL) in Australia. English Teaching: Practice and Critique, 13(1), 2438.

Cummins, J. (1981). Bilingualism and Minority Children. Ontario: Ontario Institute for Studies in Education.

Cummins, J. and Corson, D. (Eds.). (1997). Encyclopedia of Language and Education 5: Bilingual Education. Dordrecht: Kluwer Academic Publishers.

Diah, M. (1982). National Language Policy and The Writing Curriculum in Indonesia: A Case Study. Urbana: 
Curriculum Laboratory, University of Illinois.

Giroux, H. and Penna, A. (1983). 'Social Education in the Classroom: The Dynamics of the Hidden Curriculum.' In H. Giroux and D. Purpel (eds) The Hidden Curriculum and Moral Education. Berkeley, California: McCutchan Publishing Corporation. 100-121.

Glatthorn, A. A. (1987). Curriculum Renewal. Alexandria, VA: Association for Supervision and Curriculum Development.

Grosjean, F. (1989). Neurolinguists, Beware! The Bilingual Is Not Two Monolinguals in One Person. Brain and Language, 36, 3-15.

Haddock, D., Nicholls, H., and Stacey, K. (2008). Working with English Language Learners: A handbook for Teacher Aides and Bilingual Tutors. Auckland.

Hill, K. and Mcnamara, T. (2003). Assessment Research in Second Language Curriculum Intiatives. In John P. Keeves and Ryo Watanabe (eds.) International Handbook of Educational Research in the Asia-Pacific Region. Dordrecht: Kluwer Academic Publishers. pp. 629-640.

Ho, W. K. and Wong, R. Y. L. (1997). Bilingual Education in Singapore, Malaysia and Indonesia. In Cummins, J. and Corson, D. (Eds.), Encyclopedia of Language and Education, Vol.5. Dordrecht:
Kluwer Academic Publishers. pp 177-185.

Johnson, D. C. 2013. Language Policy. Basingstoke, UK: Palgrave Macmillan.

Joint Task Force on Assessment of the International Reading Association and the National Council of Teachers of English. (2010). Standards for the assessment of reading and writing. (Rev. ed.). Urbana, IL: NCTE and Newark, DE: IRA.

Krashen, S. (1982). Principles and Practice in Second Language Acquisition Language Teaching Methodology. Oxford: Pergamon Press.

Lauder, A. (2008). The Status and Function of English in Indonesia: A review of key factors. Makara, Sosial Humaniora. Vol. 12, no. 1, July 2008: 9-20.

Lin, A. M. Y. and Man, E. Y. F. (2009). Bilingual Education Southeast Asian Perspectives. Hong Kong: Hong Kong University Press.

Lindholm-Leary, K. J. (2001). Dual language education. Avon, England: Multilingual Matters.

Lowenberg, P. H. (1991). English as an additional language in Indonesia. World Englishes. Vol. LO. No. 2. pp. 127-138. 1991.

Martin D. J. and Loomis K. S. (2014). Building Teachers: A Constructivist Approach to Introducing Education, 2nd edition. Belmont: Wadsworth. 
Martin, J. (1983). What Should We Do with a Hidden Curriculum When We Find One? In H. Giroux and D. Purpel (eds) The Hidden Curriculum and Moral Education. Berkeley, California: McCutchan Publishing Corporation, 1983. 122-139.

Reynolds, A. J. and Clements. M. (2005). Parental Involvement and Children's School Success, In Evanthia N. Patrikakou, Roger P. Weissberg, Sam Redding, Herbert J. Walberg (eds.) School-Family Partnerships for Children's Success. New York: Teachers College. pp. 105-127.

Seel, N. M. (2004). Curriculum Development, Instructional Design, and In-formation Technology. In N. M. Seel \& S. Dijkstra (Eds.), Curriculum, Plans, Processes of Instructional Design: International Perspectives (pp. 131143). Mahwah, NJ: Lawrence Erlbaum Associates.
Surdyanto, A. (2016) Students' Perceptions of the Use of English at a Bilingual Setting Based on Their Kindergarten Language Background. Journal of ELT Research, [S.l.], v. 1, n. 2, p. 134-143, sep. 2016. ISSN 2527-7448. Available at: <http://journal.uhamka.ac.id/in dex.php/jer/article/view/52

Vygotsky, L. (1978). Mind in Society: The development of Higher Psychological Processes. Cambridge: Harvard University Press. 